\title{
Implications of the obesity epidemic for lipid- lowering therapy: Non-HDL cholesterol should replace LDL cholesterol as the primary therapeutic target
}

\author{
Michel R Hoenig \\ Royal Brisbane and Women's Hospital, \\ Herston, Queensland, Australia
}

Correspondence: Michel R Hoenig Clinical Sciences Building, D Floor, D7 Office, Royal Brisbane and Women's Hospital, Herston QId 4029, Australia Tel +6I 4II $024 \mid 77$

Fax +6173636325 I

Email drmhoenig@yahoo.com.au

\begin{abstract}
Obesity, metabolic syndrome and diabetes are conditions with increasing prevalence around the world. Cardiovascular risk in diabetics is often so high as to overlap with event rates observed in those with established coronary disease and this has lead to diabetes being classified as a coronary risk equivalent. However, despite the elevated risk of cardiovascular events associated with diabetes and the metabolic syndrome, these patients often have normal low density lipoprotein (LDL) cholesterol despite frequent increases in apolipoprotein B, triglycerides and nonhigh density lipoprotein (HDL) cholesterol. In contrast to LDL cholesterol, non-HDL cholesterol represents cardiovascular risk across all patient populations but is currently only recommended as a secondary target of therapy by the ATP III report for patients with hypertriglyceridemia. This article provides an overview of the studies that shown non-HDL cholesterol to be superior to LDL cholesterol in predicting cardiovascular events and presents the case for non-HDL cholesterol being the more appropriate primary target of therapy in the context of the obesity pandemic. Adopting non-HDL cholesterol as the primary therapeutic target for all patients will conceivably lead to an appropriate intensification of therapy for high risk patients with low LDL cholesterol.
\end{abstract}

Keywords: obesity, coronary artery disease, non-HDL cholesterol, LDL cholesterol, metabolic syndrome, diabetes

\section{LDL cholesterol:The current target of therapy}

Epidemiologic data from populations with and without coronary artery disease (CAD) have highlighted the importance of reducing low density lipoprotein cholesterol (LDL-C) in preventing both new-onset CAD and recurrent ischemic events (Stamler et al 1986, 1984b, 1984a; Rossouw et al 1990; Wong et al 1991; Wilson et al 1998). Indeed, there is a log-linear relationship between LDL-C and CAD risk, and this relationship holds true at low LDL-C levels (Grundy et al 2004). Not surprisingly, LDL-C was identified by the National Cholesterol Education Program (NCEP) Adult Treatment Panel (ATP) reports as being the primary focus of cholesterol-reducing therapy and successive NCEP ATP reports have recommended successively lower LDL-C goals for high risk patients (ATP III 2002). However, the ATP-III report acknowledges that when serum triglycerides (TG) are $>200 \mathrm{mg} / \mathrm{dl}$, increased remnant atherogenic lipoproteins greatly heighten risk predicted by LDL-C and this is associated with a substantially elevated very low density lipoprotein cholesterol (VLDL-C) (ATP III 2002). VLDL-C is not accounted for by the calculation of LDL-C in standard lipid panels. When serum TG is $<150 \mathrm{mg} / \mathrm{dl}$, VLDL-C is usually $<30 \mathrm{mg} / \mathrm{dl}$ and hence VLDL-C arguably makes a small contribution to the atherogenic cholesterol pool 
(1979). However, for patients with TG $>200 \mathrm{mg} / \mathrm{dl}$, non high density lipoprotein cholesterol (non-HDL-C) is identified as a secondary target of therapy with the target being $<30 \mathrm{mg} / \mathrm{dl}$ greater than the LDL-C target (ATP III 2002). Non-HDL-C is simply calculated from a standard lipid panel as total cholesterol (TC) minus HDL-C and accounts for LDL-C, VLDL-C, IDL-C, chylomicron remnants, and lipoprotein a. Non-HDL-C is highly correlated with apolipoprotein B (apoB) and therefore provides a more accurate measure of the cholesterol in atherogenic particles (ATP III 2002). While non-HDL-C is highly correlated with LDL-C ( $\mathrm{r}=0.94)$, at TG $>150 \mathrm{mg} / \mathrm{dl}$, non-HDL-C becomes displaced upwards and the correlation weakens (Abate et al 1993). Since hypertriglyceridemia affects $16 \%$ of the American population and $37 \%$ of diabetics (Shepherd 2005), non-HDL-C may be a more appropriate primary target of therapy since LDL-C may be less reliable for risk prediction in a sizeable proportion of the population (Pischon et al 2005). Moreover, non-HDL-C may be a superior predictor of CAD events regardless of TG; a 5794 person cohort from the Framingham study showed non-HDL-C to be a superior predictor of CAD events compared with LDL-C and also showed VLDL-C to predict CAD events after adjusting for LDL-C in patients with TG $>200 \mathrm{mg} / \mathrm{dl}$ and in patients with $\mathrm{TG}<200 \mathrm{mg} / \mathrm{dl}$ (Liu et al 2006). Further, VLDL-C correlated poorly $(r=0.08)$ with LDL-C and an advantage of a non-HDL-C target is that it incorporates both LDL-C and VLDL-C. The triglyceride-rich lipoproteins which are not accounted for by LDL-C measurement have been associated with both increased angiographic progression of CAD and hard clinical end points (Phillips et al 1993; Mack et al 1996; Sacks et al 2000). Further, non-HDL-C is inversely correlated to HDL-C in adults and children (Gordon et al 1989, Srinivasan et al 2002). The need to change the primary target of therapy is arguably more pressing given the increasing prevalence of obesity, diabetes, the metabolic syndrome and hypertriglyceridemia; this paper proposes that non-HDL-C should be the primary target of therapy for all patients.

\section{Diabetes, obesity, metabolic syndrome, atherogenic dyslipidemia and cardiovascular events}

Recent data from the Framingham Offspring study have shown that the incidence of type 2 diabetes in the 1990s has doubled when compared to the 1970s, with most of the absolute increase in diabetes incidence occurring in the obese as determined by body mass index (BMI) of greater than 30 (Fox et al 2006). This finding is concordant with secular trends found in the San Antonio Heart Study from 1987-1996 (Burke et al 1999). Data collected from the Framingham cohort over 5 decades has shown that the burden of cardiovascular disease is increasingly attributable to diabetes mellitus (Fox et al 2007a). Some studies have shown diabetics without previous myocardial infarction to harbor the same risk of cardiovascular death and myocardial infarction as non-diabetic patients with previous myocardial infarction (Haffner et al 1998). However, this high risk of cardiovascular events in diabetics depends on co-existing cardiovascular risk factors as shown in the Strong Heart Study and the Multiple Risk Factor Intervention Trial (MRFIT) (Vaccaro et al 1998; Howard et al 2006). Similarly, in an National Health and Nutrition Examination Survey (NHANES III) analysis, patients with diabetes but without the metabolic syndrome (only 14\% of diabetics) did not have an increased risk of CAD (Alexander et al 2003). The diagnosis of the metabolic syndrome (criteria in Table 1) describes the clustering of central adiposity with impaired fasting glucose, elevated blood pressure, high TG, and low HDL-C (Grundy 2005; Zimmet et al 2005; Pladevall et al 2006) and, like diabetes, is associated with an increased risk of cardiovascular events (Bonora et al 2000; Lakka et al 2002; Malik et al 2004; Butler et al 2006; Nigam et al 2006). Individual components of the

Table I ATP III and IDF Definitions of the metabolic syndrome (ATPIII 2002; Liberopoulos et al 2005).

\begin{tabular}{ll}
\hline IDF Criteria (first criterion compulsory plus any additional 2) & ATP III Criteria (3/5 required for diagnosis) \\
\hline $\begin{array}{l}\text { Waist circumference }>94 \mathrm{~cm} \text { in Europid males or }>80 \mathrm{~cm} \text { in Europid } \\
\text { females (with ethnic-specific values for other groups) }\end{array}$ & Waist circumference $>102 \mathrm{~cm}$ in males or $>88 \mathrm{~cm}$ in females \\
$\begin{array}{l}\text { Triglycerides }>150 \mathrm{mg} / \mathrm{dl} \text { or specific treatment for lipid abnormality } \\
\mathrm{HDL} \text { cholesterol }<40 \mathrm{mg} / \mathrm{dl} \text { in a male or }<50 \mathrm{mg} / \mathrm{dl} \text { in a female or specific }\end{array}$ & $\begin{array}{l}\text { Triglycerides }>150 \mathrm{mg} / \mathrm{dl} \\
\mathrm{HDL} \text { cholesterol }<40 \mathrm{mg} / \mathrm{dl} \text { in a male or }<50 \mathrm{mg} / \mathrm{dl} \text { in a female } \\
\text { treatment for lipid abnormality }\end{array}$ \\
$\begin{array}{l}\text { Blood pressure }>130 / 85 \text { or antihypertensive medications } \\
\text { Fasting glucose }>100 \mathrm{mg} / \mathrm{dl} \text { or previously diagnosed type 2 diabetes }\end{array}$ & $\begin{array}{l}\text { Blood pressure }>130 / 85 \text { or anti-hypertensive medications } \\
\text { Fasting glucose }>110 \mathrm{mg} / \mathrm{dl}\end{array}$ \\
\hline
\end{tabular}


metabolic syndrome, like impaired fasting glucose have been shown to be independently associated with an increased risk of cardiovascular death (Barr et al 2007). This clustering of risk factors is ultimately driven by visceral adiposity which can be quantified by waist circumference measurements or imaging studies which, with insulin resistance, drives the increased risk of cardiovascular events (Carr et al 2004; Grundy et al 2005; Zimmet et al 2005; Bonora 2006; Grundy 2006). Since obesity, metabolic syndrome, and diabetes are common conditions, treating the ensuing increased risk of cardiovascular events is of great public health significance.

NHANES data has shown roughly one third of American adults over the age of 20 to be obese, $9.3 \%$ of Americans to be diabetic with another $26 \%$ having impaired fasting glucose, and a nearly double prevalence of diabetes in minorities (Cowie et al 2006; Ogden et al 2006). The metabolic syndrome is similarly prevalent and affects roughly a quarter of Americans above the age of 20 (Ford et al 2004) and $44 \%$ of Americans over the age of 50 (Alexander et al 2003). The purpose of this paper is to discuss the alterations in lipid parameters that occur with obesity and to argue that non-HDL-C is a more appropriate target for lipid-lowering therapy than LDL-C given that, as societies, we are becoming fatter and more diabetes-prone (Flegal et al 2002; Ford et al 2003). This is especially topical as absolute risk for cardiovascular events in primary prevention and secondary prevention increasingly overlap, largely driven by the increase in obesity, metabolic syndrome and diabetes in the primary prevention setting (Vaccaro et al 1998; Howard et al 2000, 2006; ATP III 2002).

\section{The lipid profile of obesity}

In an analysis of men enrolled in the NHANES II database, increasing BMI was associated with higher TC, TG, and non-HDL-C, but with lower HDL-C. In middle-aged and older men, LDL-C did not vary with BMI (Denke et al 1993). Indeed, while excess body weight has been consistently associated with increases in TG, VLDL-C, TC, and decreased HDL-C, the effects of body weight on LDL-C have been variable (Foster et al 1987; Jacobs et al 1988; Meilahn et al 1988; Denke et al 1994). Further, while TC and LDL-C generally correlate on a population level, this correlation weakens at higher body weights where VLDL-C makes a larger contribution to TC (Wolf and Grundy 1983a). Similarly, obese children have higher TC and TG than non-obese children with no significant difference in LDL-C (Friedland et al 2002). In a pediatric population, non-HDL-C correlated with BMI and with waist circumference while LDL-C did not (Srinivasan et al 2002). Such observations in children are highly relevant to preventative cardiologists since children with higher non-HDL-C are more likely as adults to have high non-HDL-C, to be obese adults, to have hypertriglyceridemia, impaired fasting glucose, hyperinsulinemia, and low HDL-C while LDL-C levels in children are not similarly predictive (Srinivasan et al 2006). An analysis of adults in the NHANES III dataset corroborated these findings in children and showed non-HDL-C to be a significantly stronger correlate with BMI than LDL-C (Gardner et al 2000). Similarly, the accumulation of visceral adipose tissue which drives the metabolic syndrome and diabetes is associated with the lipoprotein profile of obesity which includes a normal LDL-C despite elevated cardiovascular risk (Yusuf et al 2005). Intraabdominal fat, quantified with computed tomography scanning, correlates with insulin resistance and patients with high amounts of intra-abdominal fat and greater degrees of insulin resistance have elevated TC, TG, ApoB, VLDL-C, and less HDL-C (Nieves et al 2003). Similarly, in the Framingham cohort, TC and TG were shown to correlate positively with visceral adipose tissue while HDL-C correlated negatively (Fox et al 2007b). Determination of LDL-C is not informative of these changes in lipid parameters that are concomitants of the accumulation of visceral fat.

The NHANES III data set suggests that at least 13 million US adults with CAD or CAD risk equivalents have an LDL-C of $<130 \mathrm{mg} / \mathrm{dl}$ while 5 million US adults have an LDL-C $<100 \mathrm{mg} / \mathrm{dl}$ (Case et al 2003) and hence may not qualify for drug therapy based on current ATP III guidelines. Further, most patients who develop ischemic heart disease have LDL-C levels in the 'normal' range (Stamler et al 1993) and a cross-sectional analysis from the Framingham cohort showed that men with CAD have LDL-C that is no different from those without CAD (Schaefer et al 1994). Importantly, non-HDL-C was significantly higher in CAD than in control subjects (Schaefer et al 1994) and hence the adoption of nonHDL-C as a primary target of therapy may lead to appropriate intensification of therapy. From a pathophysiologic perspective, non-HDL-C better reflects the increased cardiovascular risk associated with high apoB levels and small LDL particle size which are hallmarks of obesity.

\section{Cholesterol metabolism in obesity and insulin resistance}

Lipoprotein kinetic studies show that the liver overproduces apoB and triglycerides in the VLDL fraction in obesity and the two drivers of this process are hypertriglyceridemia and insulin resistance (McNamara et al 1987; Barrett and Watts 
2003; Chan et al 2003). Further, obesity is associated with an increase in cholesterol synthesis and a decrease in intestinal absorption (Nestel et al 1969; Miettinen 1971; Kempen et al 1988; Hoenig et al 2007) and these variables are responsive to weight loss (Miettinen 1971). In 2000, Miettinen suggested that low cholesterol absorption is a component of the metabolic syndrome (Simonen et al 2000). Not surprisingly, the changes in cholesterol metabolism in type 2 diabetics are similar to those seen in obese individuals; namely a lowered cholesterol absorption efficiency, decreased absorption marker ratios (Briones et al 1986; Gylling and Miettinen 1997; Simonen et al 2000, 2002) and increased levels of synthesis markers and cholesterol synthesis determined with sterol balance (Bennion and Grundy 1977; Gylling and Miettinen 1997; Simonen et al 2002; Nathan et al 2005; Hoenig et al 2007). The significance of these observations is that VLDL-C is an independent predictor of CAD events, after adjustment for LDL-C (Liu et al 2006). Conversely, weight loss has been shown to produce consistent reductions in VLDL-C, TG levels and increases in HDL-C with variable effects on LDL-C (Brownell and Stunkard 1981; Wolf and Grundy 1983b; Follick et al 1984; Wood et al 1988). Measuring non-HDL-C includes the cholesterol in the VLDL fraction and therefore better capitulates this shift in phenotype to increased cholesterol synthesis with obesity whereas considering LDL-C alone is uninformative. Higher BMI is associated with increases in non-HDL-C, TC, VLDL-C, and apoB, reflecting higher hepatic synthesis of VLDL and an increased number of atherogenic particles (Lamon-Fava et al 1996). In contrast to non-HDL-C, LDL-C often remains unchanged in obesity and insulin resistance.

\section{Non-HDL-C correlates better than LDL-C with apoB}

Patients with the metabolic syndrome have an increased concentration of apoB and TC despite no difference in LDL-C compared with individuals without the metabolic syndrome (Hulthe et al 2000). In this context, it is hardly surprising that apoB concentrations added to the predictive value of LDL-C in the Quebec Heart Study which was a prospective cohort followed for 13 years (St-Pierre et al 2006). Further, there was poor concordance between LDL-C and apoB values in this population, especially amongst the majority of the population in the middle quintiles of LDL-C. NonHLD-C was a superior correlate to ApoB than LDL-C and those with disproportionately elevated apoB were those with higher BMI, higher TG, lower HDL-C, and smaller LDL particles, ie, features of the metabolic syndrome (Sniderman et al 2003b). The superior correlation of non-HDL-C with apoB compared to LDL-C is also illustrated by data from the Atorvastatin Comparative Cholesterol Efficacy and Safety Study (ACCESS) investigators. Non-HDL-C correlated better with apoB than LDL-C, especially in patients with $\mathrm{CAD}$ and non-HDL-C correlated with ApoB ( $\mathrm{r}>0.90)$ across all TG strata while the correlation between LDL-C and apoB deteriorated as TG increased $(r=0.81$ if $\mathrm{TG}>250$ $\mathrm{mg} / \mathrm{dl})$ and was poorer in those with $\mathrm{CAD}(\mathrm{r}=0.81)$ than in lower risk patients without CAD $(r=0.86)$ (Ballantyne et al 2001). The measurement of apoB levels for cardiovascular risk prognostication has its supporters, especially in Canada (Genest et al 2003) and is the 'gold standard' for cardiovascular risk management according to its proponents (Walldius et al 2001; Sniderman et al 2003a). ApoB assays have been standardized and several experts have championed the inclusion of apoB measurement in treatment guidelines (Barter et al 2006). While non-HDL-C correlates well with apoB, its concordance has been relatively poorer (Barter et al 2006). However, the prognostic utility of non-HDL-C in predicting the hard clinical endpoint (discussed below) is perhaps the primary consideration for the clinician. Moreover, on a worldwide basis, the standard lipid panel remains the mainstay of lipid assessment and the adoption of non-HDL-C as the primary therapeutic target would not require clinician re-education to the same extent that adoption of apoB as a therapeutic target would. As such, to replace LDL-C as the primary therapeutic target with non-HDL-C instead of apoB may be based more on pragmatism than evidence per se.

\section{Non-HDL-C correlates better than LDL-C with small dense LDL particles}

As well as being associated with increased apoB, obesity and diabetes have been associated with a preponderance for small, dense LDL particles. Just as non-HDL-C is a better correlate of apoB than LDL-C, elevated non-HDL-C is associated with smaller LDL particle size while elevated LDL-C is not. Prospective cohort data from the Quebec Cardiovascular Study show that an increased risk of cardiovascular events is associated with a preferential accumulation of small dense LDL particles $<255 \mathrm{~A}$ (St-Pierre et al 2001, 2005). While LDL-C in patients who developed CAD was a mere $8 \%$ higher than those without disease, the increase in cholesterol carried in small LDL particles ( $<255 \mathrm{~A})$ was 40\% (St-Pierre et al 2001). As expected, individuals with a preferential accumulation of cholesterol in small dense LDL particles had higher BMI, elevated TG, lower HDL-C and higher insulin levels, which 
are all features of the metabolic syndrome (St-Pierre et al 2005). Conversely, the preferential accumulation of cholesterol in larger LDL particles $(>260 \mathrm{~A})$ was associated with a relatively reduced incidence of ischemic heart disease and fewer features of the metabolic syndrome (St-Pierre et al 2005). Similarly, in the Framingham cohort, LDL-C was not significantly different in men with and without the metabolic syndrome although those with the metabolic syndrome had a greater number of small LDL particles, a smaller average LDL size and greater apoB (Kathiresan et al 2006). While LDL particle size bears no correlation to LDL-C, patients with smaller LDL particles had higher TC, non-HDL-C and TG with lower HDL-C than those with larger LDL particle size (Hulthe et al 2000). Similarly, data from the EPIC-Norfolk Prospective Population Study has shown non-HDL-C to correlate inversely with LDL particle size $(\mathrm{p}<0.01)$ while there was no correlation between LDL-C and LDL particle size $(\mathrm{p}=0.6)$ (El Harchaoui et al 2007). Given that determination of LDL size is not part of routine patient care and LDL-C levels are usually normal or mildly elevated in those with diabetes, an alternative to LDL-C to quantify risk appears to be warranted.

\section{Non-HDL-C is superior to LDL-C in cardiovascular risk prediction}

While non-HDL-C has been correlated to cardiovascular events in epidemiologic studies (Keys et al 1984; Pocock et al 1986; Menotti et al 1992; Bos et al 2003), the purpose of this section is to describe studies that have compared the predictive value of non-HDL-C with LDL-C. Where data is available, the predictive value of non-HDL-C is also compared with apoB. While non-HDL-C levels have been associated with fatty streaks, vascular stenoses, angiographic progression of CAD, and carotid IMT (Bittner 2004), the linking of non-HDL-C to the hard clinical endpoint is of greater prognostic and therapeutic value and is crucial to effecting guideline change. Hence, this section only deals with studies that have reported hard clinical end points. These are summarized in Table 2 and selected studies are discussed herein. To the author's knowledge, this is the most comprehensive assimilation of such studies.

In a 5794 patient cohort from Framingham who were initially free from CAD, VLDL-C predicted CAD events after adjustment for LDL-C (Liu et al 2006). Further, within each LDL-C category $(<130 \mathrm{mg} / \mathrm{dl}, 130-159 \mathrm{mg} / \mathrm{dl},>160$ $\mathrm{mg} / \mathrm{dl})$, non-HDL-C (<160 mg/dl, 160-189 mg/dl, >190 $\mathrm{mg} / \mathrm{dl}$ ) was additionally predictive of CAD event rates but within each non-HDL-C category, LDL-C was not predictive of event rates (Liu et al 2006). As expected, LDL-C predicted CAD events in patients with $\mathrm{TG}<200 \mathrm{mg} / \mathrm{dl}$ (RR 1.009 per $\mathrm{mg} / \mathrm{dl}$ increase, $\mathrm{p}<0.01$ ) as did non-HDL-C (RR1.008 per $\mathrm{mg} / \mathrm{dl}$ increase, $\mathrm{p}<0.01)$. However, LDL-C lost predictive value in patients with $\mathrm{TG}>200 \mathrm{mg} / \mathrm{dl}$ while non-HDL-C remained predictive (RR1.006 per $\mathrm{mg} / \mathrm{dl}$ increase, $\mathrm{p}<0.01$ ) (Liu et al 2006). Hence, non-HDL-C is a better predictor of CAD events and can be utilized 'across the board' regardless of TG. Interestingly, a study of diabetic women enrolled in the Nurses' Health study showed the predictive value of nonHDL-C to interact with TG. For the population as a whole $(n=921)$, the multivariate hazard ratio for a fourth:first quartile non-HDL-C value was $1.97(\mathrm{p}=0.016)$ but in those with a TG $>200 \mathrm{mg} / \mathrm{dl}$, the hazard ratio for a fourth:first quartile non-HDL-C was $3.80(\mathrm{p}=0.046)$ with a $\mathrm{p}$ for interaction of 0.045 (Schulze et al 2004). The confidence intervals for the hazard ratios were however wide and overlapping. Hence while available studies have suggested that non-HDL-C is predictive regardless of $\mathrm{TG}$, of some concern are studies that have suggested that LDL-C loses predictive value in people with hypertriglyceridemia and this has been found in multiple studies. For instance, in a cohort from the Lipid Research Clinics prevalence study, increasing increments of non-HDL-C by $30 \mathrm{mg} / \mathrm{dl}$ were associated with an increasing risk of cardiovascular death (Cui et al 2001) as outlined in Table 2. However, men with LDL-C $<100 \mathrm{mg} / \mathrm{dl}$, had an increased cardiovascular mortality when compared with men with LDL-C in the $100-130 \mathrm{mg} / \mathrm{dl}$ range. Careful analysis of the group of men with LDL-C $<100 \mathrm{mg} / \mathrm{dl}$ showed the increased mortality to be confined to the group who also had TG $>200 \mathrm{mg} / \mathrm{dl}$. Similarly, an analysis of diabetics (average TG $254 \mathrm{mg} / \mathrm{dl}$ ) also suggests a dissociation between CAD death and LDL-C. Diabetics with LDL-C 100-129 mg/dl had a lower 13-year CAD mortality than diabetics with LDL-C $<100 \mathrm{mg} / \mathrm{dl}$; however, the confidence intervals were wide (Liu et al 2005). Given that hypertriglyceridemia affects $16 \%$ of the American population and 37\% of diabetics (Shepherd 2005), there is a potentially large population in which LDL-C does not reflect the risk of CAD events. Indeed, some analyses have suggested that $\mathrm{TG}$ can add prognostic information to LDL-C but not to non-HDL-C (Pischon et al 2005). Other studies have also compared the predictive value of non-HDL-C to apoB.

In 15,632 females followed in the Women's Health study, non-HDL-C and apoB were the strongest lipid measures associated with cardiovascular end points and these two measures were highly correlated $(r=0.87)$ (see Table 2 ) (Ridker et al 2005). ApoB was not superior to non-HDL-C in 
Table 2 A summary of studies that have compared non-HDL-C to either LDL-C or ApoB for prediction of cardiovascular events

\begin{tabular}{|c|c|c|c|c|c|c|c|c|}
\hline \multirow[t]{2}{*}{ Population } & \multirow[t]{2}{*}{$\mathbf{N}$} & \multirow[t]{2}{*}{ End point } & \multirow{2}{*}{$\begin{array}{l}\text { Average } \\
\text { follow up } \\
\text { (years) }\end{array}$} & \multirow[b]{2}{*}{$\begin{array}{l}\text { Type of } \\
\text { analysis and } \\
\text { reference } \\
\text { (comparator) } \\
\text { group for the } \\
\text { cohort }\end{array}$} & \multicolumn{3}{|c|}{ HR ( $95 \% \mathrm{Cl}$ or $\mathrm{p}$ value) } & \multirow[t]{2}{*}{ Reference } \\
\hline & & & & & Non-HDL-C & LDL-C & ApoB & \\
\hline $\begin{array}{l}\text { Men and women } \\
\text { in the Fram- } \\
\text { ingham cohort, } \\
\text { Framingham } \\
\text { Offspring } \\
\text { cohort, Lipid } \\
\text { Research Clinics } \\
\text { Prevalence Study } \\
\text { and the Mul- } \\
\text { tiple Risk Factor } \\
\text { Intervention } \\
\text { Trials; } 5 \% \text { diabet- } \\
\text { ics; average BMI } \\
26.0 ; \text { average } \\
\text { TG I57 mg/dl; } \\
\text { average VLDL-C } \\
29 \text { mg/dl }\end{array}$ & $\begin{array}{l}\text { I938I; } \\
18363 \\
\text { non- } \\
\text { diabetics } \\
\text { and } 1018 \\
\text { diabetics }\end{array}$ & CAD death & 13 & $\begin{array}{l}\text { Multivariate; } \\
\text { Comparator } \\
\text { for analyses is } \\
\text { non-diabetics } \\
\text { with LDL-C } \\
<100 \mathrm{mg} / \mathrm{dl} \text { or } \\
\text { non-diabetics } \\
\text { with non-HDL- } \\
\mathrm{C}<130 \mathrm{mg} / \mathrm{dl}\end{array}$ & $\begin{array}{l}\text { DIABETICS } \\
\text { Non-HDL- } \\
\text { C<I30 mg/dl; } \\
2.73 \text { (I.27-5.87) } \\
\text { Non-HDL-C } \\
\text { I30-I59 mg/dl; } \\
2.73(\mathrm{I} .60-4.66) \\
\text { Non-HDL-C } \\
>160 \mathrm{mg} / \mathrm{dl} ; 3.68 \\
(2.5 \mathrm{I}-5.39) \\
\text { NON-DIABET- } \\
\text { ICS } \\
\text { Non-HDL-C } \\
\text { I30-I59 mg/dl; } \\
0.95(0.65-I .39) \\
\text { Non-HDL-C } \\
>160 \mathrm{mg} / \mathrm{dl} ; 2.1 \mathrm{I} \\
(\mathrm{I} .52-2.9 \mid)\end{array}$ & 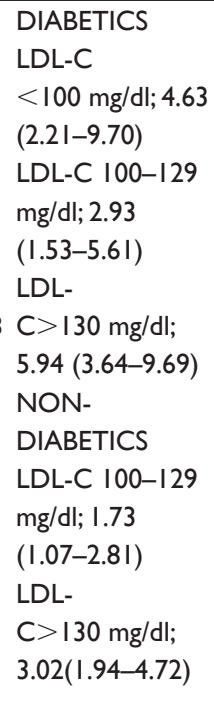 & NA & $\begin{array}{l}\text { Liu et al } \\
2005\end{array}$ \\
\hline $\begin{array}{l}\text { Women free } \\
\text { of cardiovascu- } \\
\text { lar disease at } \\
\text { baseline enrolled } \\
\text { in the Women's } \\
\text { Health Study; } 3 \% \\
\text { diabetics; aver- } \\
\text { age BMI } 26.3\end{array}$ & 15632 & $\begin{array}{l}\text { Cardiovascular } \\
\text { death or non-fatal } \\
\text { myocardial infarc- } \\
\text { tion, stroke or } \\
\text { coronary revascu- } \\
\text { larization. }\end{array}$ & 10 & $\begin{array}{l}\text { Multivariate; in } \\
\text { each analysis, the } \\
\text { fifth quintile (Q5) } \\
\text { is compared to } \\
\text { the reference } \\
\text { first quintile } \\
\text { (QI) }\end{array}$ & $\begin{array}{l}\text { Q5:QI } \\
(>191 \mathrm{mg} / \mathrm{dl} \text { ver- } \\
\text { sus }<123 \mathrm{mg} / \mathrm{dl}) ; \\
2.51(1.69-3.72)\end{array}$ & $\begin{array}{l}\text { Q5:QI } \\
(>154 \mathrm{mg} / \mathrm{dl} \text { ver- } \\
\text { sus }<98 \mathrm{mg} / \mathrm{dl}) ; \\
1.62(1.17-2.25)\end{array}$ & $\begin{array}{l}\text { Q5:QI } \\
(>126 \mathrm{mg} / \mathrm{dl} \text { ver- } \\
\text { sus }<79 \mathrm{mg} / \mathrm{dl}) ; \\
2.50(1.68-3.72)\end{array}$ & $\begin{array}{l}\text { Ridker } \\
\text { et al } 2005\end{array}$ \\
\hline $\begin{array}{l}\text { Men and women } \\
\text { free of CAD at } \\
\text { baseline; Fram- } \\
\text { ingham cohort; } \\
6.8 \% \text { diabetics; } \\
\text { average BMI } \\
24 \text {; average } \\
\text { TG II I mg/dl; } \\
\text { average VLDL-C } \\
25 \mathrm{mg} / \mathrm{dl}\end{array}$ & 5794 & $\begin{array}{l}\text { Fatal and non-fatal } \\
\text { myocardial infarc- } \\
\text { tion, acute coronary } \\
\text { insufficiency or sud- } \\
\text { den cardiovascular } \\
\text { death }\end{array}$ & 22 & $\begin{array}{l}\text { Multivariate; } \\
\text { Comparator } \\
\text { for LDL-C } \\
\text { analysis is LDL-C } \\
<130 \mathrm{mg} / \mathrm{dl} \text { and } \\
\text { for non-HDL- } \\
\mathrm{C}<160 \mathrm{mg} / \mathrm{dl}\end{array}$ & $\begin{array}{l}\text { Non-HDL-C } \\
\text { I60-I89 mg/dl; } \\
\text { I.64 (I.I3-2.40) } \\
\text { Non-HDL-C } \\
>190 \mathrm{mg} / \mathrm{dl} ; 2.2 \mathrm{I} \\
(\mathrm{I} .57-3 . \mathrm{I}) \\
\text { I.008 per mg/dl } \\
\text { TG }<200 \mathrm{mg} / \mathrm{dl} \\
(\mathrm{p}<0.0 \mathrm{I}) \\
\text { I.006 per mg/dl } \\
\text { TG }>200 \mathrm{mg} / \mathrm{dl} \\
(\mathrm{p}<0.0 \mathrm{I})\end{array}$ & $\begin{array}{l}\text { LDL-C I30-I59 } \\
\mathrm{mg} / \mathrm{dl} ; 1.50 \\
(\mathrm{I} .05-2.15) \\
\text { LDL- } \\
\mathrm{C}>160 \mathrm{mg} / \mathrm{dl} ; \\
2.04(\mathrm{I} .44-2.90) \\
1.009 \mathrm{per} \mathrm{mg/dl} \\
\mathrm{TG}<200 \mathrm{mg} / \mathrm{dl} \\
\mathrm{I} .004 \mathrm{per} \mathrm{mg/dl} \\
\mathrm{TG}>200 \mathrm{mg} / \mathrm{dl} \\
(\mathrm{p}=\mathrm{NS})\end{array}$ & NA & $\begin{array}{l}\text { Liu et al } \\
2006\end{array}$ \\
\hline $\begin{array}{l}\text { Patients enrolled } \\
\text { in the SHEP } \\
\text { trial; age>60 } \\
\text { with mean } \\
\text { blood pressure } \\
\text { I70/77 mmHg; } \\
\text { I0\% diabetics; } \\
\text { average BMI } \\
27.5 \text {; average TG } \\
\text { I } 44 \text { mg/dl; I3\% } \\
\text { on lipid-lowering } \\
\text { therapy }\end{array}$ & 4736 & $\begin{array}{l}\text { Non-fatal myocar- } \\
\text { dial infarction, CAD } \\
\text { death }\end{array}$ & 4.5 & $\begin{array}{l}\text { Multivariate; risk } \\
\text { is expressed per } \\
40 \mathrm{mg} / \mathrm{dl} \text { increase } \\
\text { in lipid param- } \\
\text { eters }\end{array}$ & $1.32(1.13-1.54)$ & $1.30(1.09-1.54)$ & NA & $\begin{array}{l}\text { Frost et al } \\
1996\end{array}$ \\
\hline
\end{tabular}

(Continued) 
Table 2 (Continued)

\begin{tabular}{|c|c|c|c|c|c|c|c|c|}
\hline \multirow[t]{2}{*}{ Population } & \multirow[t]{2}{*}{$\mathbf{N}$} & \multirow[t]{2}{*}{ End point } & \multirow{2}{*}{$\begin{array}{l}\text { Average } \\
\text { follow up } \\
\text { (years) }\end{array}$} & \multirow[b]{2}{*}{$\begin{array}{l}\text { Type of } \\
\text { analysis and } \\
\text { reference } \\
\text { (comparator) } \\
\text { group for the } \\
\text { cohort }\end{array}$} & \multicolumn{3}{|c|}{ HR (95\% $\mathrm{Cl}$ or $\mathrm{p}$ value) } & \multirow[t]{2}{*}{ Reference } \\
\hline & & & & & Non-HDL-C & LDL-C & ApoB & \\
\hline $\begin{array}{l}\text { Men and women } \\
\text { free of cardio- } \\
\text { vascular disease } \\
\text { at baseline; indi- } \\
\text { viduals enrolled } \\
\text { in the Lipid } \\
\text { research clinics } \\
\text { prevalence pro- } \\
\text { gram; } 4 \% \text { diabet- } \\
\text { ics; average BMI } \\
26.2 \text {; average } \\
\text { TG I36 mg/dl; } \\
\text { average VLDL-C } \\
27 \text { mg/dl; } 2 \% \text { on } \\
\text { lipid-lowering } \\
\text { therapy }\end{array}$ & 4462 & $\begin{array}{l}\text { Cardiovascular } \\
\text { death }\end{array}$ & 19 & $\begin{array}{l}\text { Corrected for } \\
\text { age; compara- } \\
\text { tor for LDL-C } \\
\text { analysis is LDL-C } \\
<130 \mathrm{mg} / \mathrm{dl} \text { and } \\
\text { for non-HDL- } \\
\mathrm{C}<160 \mathrm{mg} / \mathrm{dl}\end{array}$ & $\begin{array}{l}30 \mathrm{mg} / \mathrm{dl} \text { incre- } \\
\text { ments cor- } \\
\text { respond to a } \\
19 \% \text { increase in } \\
\text { cardiovascular } \\
\text { death in men and } \\
11 \% \text { in women }\end{array}$ & $\begin{array}{l}30 \mathrm{mg} / \mathrm{dl} \text { incre- } \\
\text { ments cor- } \\
\text { respond to a } \\
15 \% \text { increase in } \\
\text { cardiovascular } \\
\text { death in men and } \\
8 \% \text { in women }\end{array}$ & NA & $\begin{array}{l}\text { Cui et al } \\
2001\end{array}$ \\
\hline $\begin{array}{l}\text { Chinese men } \\
\text { and women free } \\
\text { of cardiovascular } \\
\text { disease at base- } \\
\text { line; I } 3 \% \text { diabet- } \\
\text { ics; average BMI } \\
23.5 \text {; average TG } \\
\text { I } 27 \mathrm{mg} / \mathrm{dl} \text {. }\end{array}$ & 3568 & $\begin{array}{l}\text { non-fatal myocar- } \\
\text { dial infarction, fatal } \\
\text { CAD or coronary } \\
\text { revascularization }\end{array}$ & 13.6 & $\begin{array}{l}\text { Multivariate; in } \\
\text { each analysis, the } \\
\text { fifth quintile (Q5) } \\
\text { is compared to } \\
\text { the reference } \\
\text { first quintile } \\
\text { (QI) }\end{array}$ & $\begin{array}{l}\text { Q5:QI; I.98 } \\
\text { (1.00-3.92) }\end{array}$ & $\begin{array}{l}\text { Q5:QI; I.86 } \\
(1.00-3.46)\end{array}$ & $\begin{array}{l}\text { Q5:QI; } 2.74 \\
(1.45-5.19)\end{array}$ & $\begin{array}{l}\text { Chien } \\
\text { et al } 2007\end{array}$ \\
\hline $\begin{array}{l}\text { Men and women } \\
\text { free of CAD at } \\
\text { baseline; Fram- } \\
\text { ingham cohort; } \\
4 \% \text { diabetics. } \\
\text { This Framing- } \\
\text { ham cohort is } \\
\text { different to that } \\
\text { studied by Liu } \\
\text { et al (I3). }\end{array}$ & 3322 & $\begin{array}{l}\text { myocardial } \\
\text { infarction, angina } \\
\text { pectoris, coronary } \\
\text { insufficiency or car- } \\
\text { diovascular death }\end{array}$ & 15 & $\begin{array}{l}\text { Multivariate; } \\
\text { Hazard ratios } \\
\text { expressed per } \\
\text { increase in one } \\
\text { standard devia- } \\
\text { tion of the popu- } \\
\text { lation. Analyses } \\
\text { were stratified } \\
\text { based on sex. }\end{array}$ & $\begin{array}{l}\text { MALE } \\
\text { I.22 (I.06-I.40) } \\
\text { per one stan- } \\
\text { dard deviation } \\
\text { increase } \\
\text { FEMALE } \\
\text { I.28 (I.06-I.56) } \\
\text { per one stan- } \\
\text { dard deviation } \\
\text { increase }\end{array}$ & $\begin{array}{l}\text { MALE } \\
\text { I.I I ( } 0.97-I .27) \\
\text { per one standard } \\
\text { deviation increase } \\
\text { FEMALE } \\
\text { I.20 (0.99-I.46) } \\
\text { per one standard } \\
\text { deviation increase }\end{array}$ & $\begin{array}{l}\text { MALE } \\
\text { I.37 (I.20-I.57) } \\
\text { per one standard } \\
\text { deviation increase } \\
\text { FEMALE } \\
\text { I.38 (I.I5-I.67) } \\
\text { per one standard } \\
\text { deviation increase }\end{array}$ & $\begin{array}{l}\text { Ingelsson } \\
\text { et al } 2007\end{array}$ \\
\hline $\begin{array}{l}\text { I003 men and } \\
\text { women with a } \\
\text { CAD event and } \\
\text { I885 matched } \\
\text { controls } \\
\text { enrolled in the } \\
\text { EPIC-Norfolk } \\
\text { study designed } \\
\text { to study deter- } \\
\text { minants of can- } \\
\text { cer. Participants } \\
\text { were apparently } \\
\text { healthy and free } \\
\text { of cardiovas- } \\
\text { cular disease } \\
\text { at baseline. } 3 \% \\
\text { diabetics; aver- } \\
\text { age BMI } 27 \text {; }\end{array}$ & 2888 & $\begin{array}{l}\text { Hospital admission } \\
\text { for CAD or death } \\
\text { secondary to CAD. }\end{array}$ & $\begin{array}{l}6 \text { years } \\
\text { follow } \\
\text { up; case } \\
\text { control } \\
\text { design }\end{array}$ & $\begin{array}{l}\text { Multivariate; in } \\
\text { each analysis, } \\
\text { the fourth } \\
\text { quartile (Q4) } \\
\text { is compared to } \\
\text { the reference } \\
\text { first quartile } \\
\text { (QI). This study } \\
\text { reported odds } \\
\text { ratio and not } \\
\text { hazard ratios } \\
\text { (HR) }\end{array}$ & $\begin{array}{l}\text { Q4:QI; } \\
\text { I.63(I.26-2.1I) }\end{array}$ & $\begin{array}{l}\text { Q4:QI; I.55 } \\
(1.22-1.96)\end{array}$ & NA & $\begin{array}{l}\text { El Harcha- } \\
\text { oui et al } \\
2007\end{array}$ \\
\hline
\end{tabular}


Table 2 (Continued)

\begin{tabular}{|c|c|c|c|c|c|c|c|c|}
\hline \multirow[t]{2}{*}{ Population } & \multirow[t]{2}{*}{$\mathbf{N}$} & \multirow[t]{2}{*}{ End point } & \multirow{2}{*}{$\begin{array}{l}\text { Average } \\
\text { follow up } \\
\text { (years) }\end{array}$} & \multirow[b]{2}{*}{$\begin{array}{l}\text { Type of } \\
\text { Analysis and } \\
\text { reference } \\
\text { (comparator) } \\
\text { group for the } \\
\text { cohort }\end{array}$} & \multicolumn{3}{|c|}{ HR (95\% Cl or $p$ value) } & \multirow[t]{2}{*}{ Reference } \\
\hline & & & & & Non-HDL-C & LDL-C & ApoB & \\
\hline \multicolumn{9}{|l|}{$\begin{array}{l}\text { average TG } \\
\text { I48 mg/dl; 0\% } \\
\text { using lipid-low- } \\
\text { ering therapy }\end{array}$} \\
\hline $\begin{array}{l}\text { Men and women } \\
\text { with myocardial } \\
\text { infarction or } \\
\text { angina pectoris } \\
\text { enrolled in the } \\
\text { placebo arm of } \\
\text { the } 4 \mathrm{~S} \text { study; TG } \\
<220 \mathrm{mg} / \mathrm{dl} \text { for } \\
\text { enrolment; }\end{array}$ & 2223 & $\begin{array}{l}\text { CAD death or } \\
\text { non-fatal myocardial } \\
\text { infarction }\end{array}$ & 5.4 & $\begin{array}{l}\text { Multivariate; } \\
\text { data reported } \\
\text { as relative risk } \\
\text { reductions }\end{array}$ & $\begin{array}{l}\text { I6.4\% risk reduc- } \\
\text { tion }(p=0.002) \\
\text { per } 39 \mathrm{mg} / \mathrm{dl} \\
\text { decrease in non- } \\
\text { HDL-C }\end{array}$ & $\begin{array}{l}\text { I } 2.8 \% \text { risk reduc- } \\
\text { tion }(p=0.024) \\
\text { per } 39 \mathrm{mg} / \mathrm{dl} \\
\text { decrease in } \\
\text { LDL-C }\end{array}$ & $\begin{array}{l}5.3 \% \text { risk reduc- } \\
\text { tion }(p=0.0025) \\
\text { per } 10 \mathrm{mg} / \mathrm{dl} \\
\text { decrease in ApoB }\end{array}$ & $\begin{array}{l}\text { Pedersen } \\
\text { et al } 1998\end{array}$ \\
\hline $\begin{array}{l}\text { Men and women } \\
\text { with myocardial } \\
\text { infarction or } \\
\text { angina pectoris } \\
\text { enrolled in the } \\
\text { treatment arm } \\
\text { (Simvastatin } 20 \\
\text { or } 40 \mathrm{mg} \text {; aver- } \\
\text { age } 27 \mathrm{mg} \text { ) of } \\
\text { the } 4 \mathrm{~S} \text { study; TG } \\
<220 \mathrm{mg} / \mathrm{dl} \text { for } \\
\text { enrolment; }\end{array}$ & 2221 & $\begin{array}{l}\text { CAD death or } \\
\text { non-fatal myocardial } \\
\text { infarction }\end{array}$ & 5.4 & $\begin{array}{l}\text { Multivariate; } \\
\text { data reported } \\
\text { as relative risk } \\
\text { reductions. The } \\
\text { absolute reduc- } \\
\text { tions in lipid } \\
\text { parameters at } \\
\text { one year post- } \\
\text { randomization } \\
\text { were assessed } \\
\text { for prognostic } \\
\text { significance over } \\
\text { the study period }\end{array}$ & $\begin{array}{l}24.9 \% \text { risk reduc- } \\
\text { tion }(\mathrm{p}=0.002) \\
\text { per } 39 \mathrm{mg} / \mathrm{dl} \\
\text { decrease in non- } \\
\text { HDL-C } \\
\mathrm{I.7 \%} \text { reduction in } \\
\text { events }(0.9-2.4) \\
\text { per } \mathrm{I} \% \text { reduction } \\
\text { in non-HDL-C }\end{array}$ & $\begin{array}{l}27.8 \% \text { risk reduc- } \\
\text { tion }(\mathrm{P}=0.024) \\
\text { per } 39 \mathrm{mg} / \mathrm{dl} \\
\text { decrease in } \\
\text { LDL-C } \\
1.7 \% \text { reduction in } \\
\text { events }(1.0-2.4) \\
\text { per I\% reduction } \\
\text { in LDL-C }\end{array}$ & $\begin{array}{l}8.8 \% \text { risk reduc- } \\
\text { tion }(\mathrm{P}=0.0025) \\
\text { per } 10 \mathrm{mg} / \mathrm{dl} \\
\text { decrease in ApoB } \\
\mathrm{I} .1 \% \text { reduction in } \\
\text { events }(0.3-\mathrm{I} .8) \\
\text { per } \mathrm{I} \% \text { reduction } \\
\text { in ApoB }\end{array}$ & $\begin{array}{l}\text { Pedersen } \\
\text { et al } 1998\end{array}$ \\
\hline $\begin{array}{l}\text { Diabetics free } \\
\text { of cardiovascu- } \\
\text { lar disease at } \\
\text { baseline from } \\
\text { American Indian } \\
\text { Communities } \\
\text { (Strong Heart } \\
\text { Study); I00\% dia- } \\
\text { betics; average } \\
\text { BMI 32; average } \\
\text { TG I44 mg/dl; }\end{array}$ & 2108 & $\begin{array}{l}\text { Cardiovascular } \\
\text { death or non-fatal } \\
\text { CAD, myocardial } \\
\text { infarction or stroke. }\end{array}$ & 9 & $\begin{array}{l}\text { Multivariate; } \\
\text { values of LDL-C } \\
\text { or non-HDL-C } \\
\text { were divided } \\
\text { into tertiles and } \\
\text { in each analysis, } \\
\text { the third tertile } \\
\text { (T3) is compared } \\
\text { to the reference } \\
\text { first tertile }(\mathrm{TI})\end{array}$ & 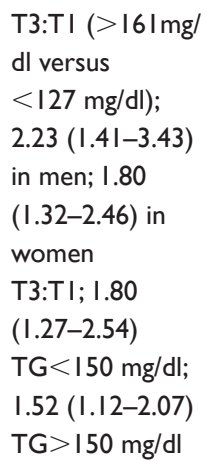 & 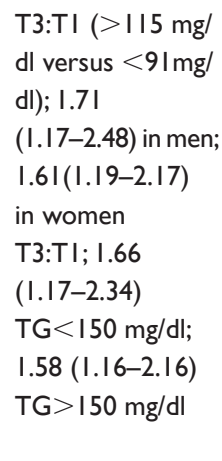 & NA & $\begin{array}{l}\text { Lu et al } \\
2003\end{array}$ \\
\hline $\begin{array}{l}\text { Men of Japanese } \\
\text { ancestry living } \\
\text { in Oahu (The } \\
\text { Honolulu Heart } \\
\text { Study) free of } \\
\text { CAD at baseline }\end{array}$ & $|75|$ & $\begin{array}{l}\text { Fatal CAD event or } \\
\text { non-fatal myocardial } \\
\text { infarction }\end{array}$ & 16 & $\begin{array}{l}\text { Multivariate; risk } \\
\text { is expressed per } \\
20 \mathrm{mg} / \mathrm{dl} \text { increase } \\
\text { in lipid param- } \\
\text { eters; stratified } \\
\text { as middle aged } \\
\text { (50-64 years old) } \\
\text { or elderly (65-74 } \\
\text { years old) }\end{array}$ & $\begin{array}{l}\text { MIDDLE AGE } \\
\text { I.I8 (I.09-I.29) } \\
\text { ELDERLY } \\
1.30(1.11-1.53)\end{array}$ & $\begin{array}{l}\text { MIDDLE AGE } \\
1.12(1.02-1.23) \\
\text { ELDERLY } \\
1.24(1.05-1.48)\end{array}$ & NA & $\begin{array}{l}\text { Reed and } \\
\text { Benfante } \\
1992\end{array}$ \\
\hline
\end{tabular}

(Continued) 
Table 2 (Continued)

\begin{tabular}{|c|c|c|c|c|c|c|c|c|}
\hline \multirow[t]{2}{*}{ Population } & \multirow[t]{2}{*}{$\mathbf{N}$} & \multirow[t]{2}{*}{ End point } & \multirow{2}{*}{$\begin{array}{l}\text { Average } \\
\text { follow up } \\
\text { (years) }\end{array}$} & \multirow[b]{2}{*}{$\begin{array}{l}\text { Type of } \\
\text { analysis and } \\
\text { reference } \\
\text { (comparator) } \\
\text { group for the } \\
\text { cohort }\end{array}$} & \multicolumn{3}{|c|}{ HR ( $95 \% \mathrm{Cl}$ or $\mathrm{p}$ value) } & \multirow[t]{2}{*}{ Reference } \\
\hline & & & & & $\overline{\text { Non-HDL-C }}$ & LDL-C & ApoB & \\
\hline $\begin{array}{l}\text { Mediterra- } \\
\text { nean men and } \\
\text { women followed } \\
\text { prospectively; } \\
\text { I00\% diabetics; } \\
\text { average BMI } \\
27 \text {; average TG } \\
138 \text { mg/dl }\end{array}$ & 1565 & $\begin{array}{l}\text { Cardiovascular } \\
\text { mortality }\end{array}$ & 11 & $\begin{array}{l}\text { Multivariate; } \\
\text { analyses strati- } \\
\text { fied based on age } \\
<70 \text { and }>70 \\
\text { years old } \\
\text { comparator } \\
\text { for LDL-C } \\
\text { analysis is LDL-C } \\
<\text { III mg/dl and } \\
\text { for non-HDL- } \\
\mathrm{C}<137 \mathrm{mg} / \mathrm{dl} \\
\text { and for ApoB } \\
<77 \mathrm{mg} / \mathrm{dl}\end{array}$ & 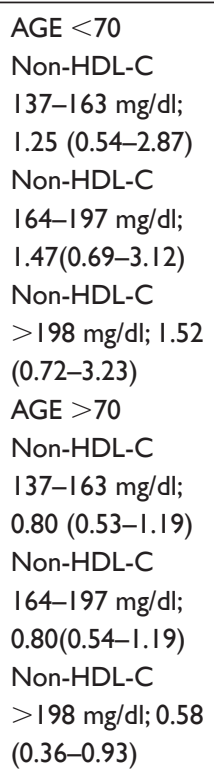 & 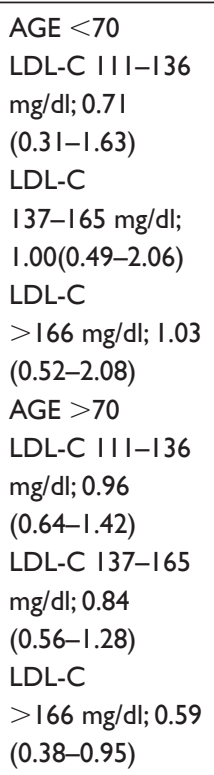 & $\begin{array}{l}\text { AGE }<70 \\
\text { ApoB 78-I0I } \\
\mathrm{mg} / \mathrm{dl} ; \mathrm{I} .33 \\
(0.56-3.15) \\
\text { ApoB } \\
\text { I0I-I26 mg/dl; } \\
\mathrm{I} .94(0.84-4.49) \\
\text { ApoB }>127 \\
\mathrm{mg} / \mathrm{dl} ; 2.86 \\
(\mathrm{I} .22-6.67) \\
\text { AGE }>70 \\
\text { ApoB } 78-10 \mathrm{I} \\
\mathrm{mg} / \mathrm{dl} ; \mathrm{I} .18 \\
(0.73-1.9 \mathrm{I}) \\
\text { ApoB } \\
\text { I0I-I26 mg/dl; } \\
\mathrm{I} .69(\mathrm{I} .08-2.63) \\
\text { ApoB }>127 \\
\mathrm{mg} / \mathrm{dl} ; \mathrm{I} .50 \\
(0.93-2.4 \mathrm{I})\end{array}$ & $\begin{array}{l}\text { Bruno } \\
\text { et al } 2006\end{array}$ \\
\hline $\begin{array}{l}\text { Patients enrolled } \\
\text { in the BARI trial; } \\
\text { all had multi- } \\
\text { vessel CAD; } \\
\text { I8\% diabetics; } \\
\text { average TG I } 84 \\
\text { mg/dl; I3\% on } \\
\text { lipid-lowering } \\
\text { therapy }\end{array}$ & 1514 & $\begin{array}{l}\text { non-fatal myocardial } \\
\text { infarction }\end{array}$ & & $\begin{array}{l}\text { Multivariate; risk } \\
\text { is expressed per } \\
10 \mathrm{mg} / \mathrm{dl} \text { increase } \\
\text { in lipid param- } \\
\text { eters }\end{array}$ & $\begin{array}{l}1.049 \\
(1.006-1.093)\end{array}$ & $\begin{array}{l}\text { NS I.033 } \\
(0.98 I-1.088)\end{array}$ & NA & $\begin{array}{l}\text { Bittner } \\
\text { et al } 2002\end{array}$ \\
\hline $\begin{array}{l}\text { Diabetic cohort } \\
16 \% \text { with previ- } \\
\text { ous myocardial } \\
\text { infarction; } \\
\text { I00\% diabetics; } \\
\text { average BMI 29; } \\
\text { average TG } 230 \\
\text { mg/dl }\end{array}$ & 1059 & CAD death & 7 & Multivariate; & $\begin{array}{l}\text { I.6 }(1.2-2.3) \\
\text { for non-HDL- } \\
C>200 \mathrm{mg} / \mathrm{dl} \\
\text { versus }<200 \\
\mathrm{mg} / \mathrm{dl} ;\end{array}$ & $\begin{array}{l}\text { NS I.3 (0.9-I.8); } \\
\text { for LDL-C } \\
>160 \mathrm{mg} / \mathrm{dl} \text { ver- } \\
\text { sus }<160 \mathrm{mg} / \mathrm{dl}\end{array}$ & NA & $\begin{array}{l}\text { Lehto et al } \\
1997\end{array}$ \\
\hline $\begin{array}{l}\text { Diabetic } \\
\text { women free of } \\
\text { cardiovascu- } \\
\text { lar disease at } \\
\text { baseline enrolled } \\
\text { in the Nurses' } \\
\text { Health study; } \\
\text { 100\% diabetics; } \\
\text { average BMl } \\
30 \text {; average TG } \\
200 \text { mg/dl; } 4 \% \\
\text { using lipid-low- } \\
\text { ering therapy }\end{array}$ & 921 & $\begin{array}{l}\text { Fatal CAD event, } \\
\text { non-fatal myocar- } \\
\text { dial infarction or } \\
\text { coronary revascu- } \\
\text { larization }\end{array}$ & 10 & $\begin{array}{l}\text { Multivariate; in } \\
\text { each analysis, } \\
\text { the fourth } \\
\text { quartile (Q4) } \\
\text { is compared to } \\
\text { the reference } \\
\text { first quartile } \\
\text { (QI). Non- } \\
\text { HDL-C is even } \\
\text { more predictive } \\
\text { in those with } \\
\text { TG }>200 \text { mg/dl; } \\
\text { discussed in text. }\end{array}$ & $\begin{array}{l}\text { Q4:QI (quartile } \\
\text { median } 224 \\
\mathrm{mg} / \mathrm{dl} \text { versus } \\
\text { I26 mg/d); } 1.97 \\
(\mathrm{I} .14-3.43)\end{array}$ & $\begin{array}{l}\text { Q4:QI (quartile } \\
\text { median } 179 \mathrm{mg} / \mathrm{dl} \\
\text { versus } 98 \mathrm{mg} / \mathrm{dl}) ; \\
\text { I.93 (I.15-3.22) }\end{array}$ & $\begin{array}{l}\text { Q4:QI (quartile } \\
\text { median I3I mg/dl } \\
\text { versus } 74 \mathrm{mg} / \mathrm{dl}) ; \\
\text { I.78 }(\mathrm{I} .02-3.1 \mathrm{I})\end{array}$ & $\begin{array}{l}\text { Schulze } \\
\text { et al } 2004\end{array}$ \\
\hline
\end{tabular}


Table 2 (Continued)

\begin{tabular}{|c|c|c|c|c|c|c|c|c|}
\hline \multirow[t]{2}{*}{ Population } & \multirow[t]{2}{*}{$\mathbf{N}$} & \multirow[t]{2}{*}{ End point } & \multirow{2}{*}{$\begin{array}{l}\text { Average } \\
\text { Follow up } \\
\text { (years) }\end{array}$} & \multirow[b]{2}{*}{$\begin{array}{l}\text { Type of } \\
\text { analysis and } \\
\text { reference } \\
\text { (comparator) } \\
\text { group for the } \\
\text { cohort }\end{array}$} & \multicolumn{3}{|c|}{ HR (95\% Cl or p value) } & \multirow[t]{2}{*}{ Reference } \\
\hline & & & & & Non-HDL-C & LDL-C & ApoB & \\
\hline $\begin{array}{l}\text { Diabetic } \\
\text { men free of } \\
\text { cardiovascu- } \\
\text { lar disease at } \\
\text { baseline enrolled } \\
\text { in the Health } \\
\text { Professionals' } \\
\text { follow up study; } \\
\text { I00\% diabetics; } \\
\text { average BMI } \\
27.1 \text {; average TG } \\
\text { I82 mg/dl; } 9 \% \\
\text { on lipid-lowering } \\
\text { therapy }\end{array}$ & 746 & $\begin{array}{l}\text { Fatal CAD, non-fatal } \\
\text { myocardial infarc- } \\
\text { tion, fatal stroke, } \\
\text { non-fatal stroke, } \\
\text { coronary revascu- } \\
\text { larization }\end{array}$ & & $\begin{array}{l}\text { Multivariate; in } \\
\text { each analysis, } \\
\text { the fourth } \\
\text { quartile (Q4) is } \\
\text { compared to the } \\
\text { reference first } \\
\text { quartile (QI) }\end{array}$ & $\begin{array}{l}\text { Q4:QI } \\
(>195 \mathrm{mg} / \mathrm{dl} \text { ver- } \\
\text { sus < }<43 \mathrm{mg} / \mathrm{dl}) \\
2.25(1.24-4.08)\end{array}$ & $\begin{array}{l}\text { Q4:QI } \\
(>149 \mathrm{mg} / \mathrm{dl} \text { versus } \\
<102 \mathrm{mg} / \mathrm{dl}) ; \mathrm{NS} \\
\mathrm{I} .63(0.94-2.8 \mathrm{I})\end{array}$ & $\begin{array}{l}\text { Q4:QI } \\
(>119 \mathrm{mg} / \mathrm{dl} \text { ver- } \\
\text { sus <89 mg/dl); } \\
2.31(1.25-4.27)\end{array}$ & $\begin{array}{l}\text { Jiang et al } \\
2004\end{array}$ \\
\hline $\begin{array}{l}243 \text { men with } \\
\text { a CAD event } \\
\text { enrolled in the } \\
\text { Health Profes- } \\
\text { sionals' follow } \\
\text { up study and } \\
496 \text { matched } \\
\text { controls; } 6 \% \\
\text { diabetics; aver- } \\
\text { age BMI } 25.8 \text {; } \\
\text { average TG } \\
\text { I30mg/dl; } 0 \% \text { on } \\
\text { lipid-lowering } \\
\text { therapy }\end{array}$ & 739 & $\begin{array}{l}\text { Fatal CAD or } \\
\text { non-fatal myocardial } \\
\text { infarction }\end{array}$ & $\begin{array}{l}6 \text { years } \\
\text { follow } \\
\text { up; case } \\
\text { control } \\
\text { design }\end{array}$ & $\begin{array}{l}\text { Multivariate; in } \\
\text { each analysis, the } \\
\text { fifth quintile (Q5) } \\
\text { is compared to } \\
\text { the reference } \\
\text { first quintile } \\
\text { (QI) }\end{array}$ & $\begin{array}{l}\text { Q5:QI; } 2.75 \\
(1.62-4.67)\end{array}$ & $\begin{array}{l}\text { Q5:QI; } 2.07 \\
(1.24-3.45)\end{array}$ & $\begin{array}{l}\text { Q5:QI; } 2.98 \\
(1.76-5.06)\end{array}$ & $\begin{array}{l}\text { Pischon } \\
\text { et al } 2005\end{array}$ \\
\hline $\begin{array}{l}\text { I00 patients } \\
\text { with non-fatal } \\
\text { myocardial } \\
\text { infarction } \\
\text { before the age } \\
\text { of } 36 \text { and } 100 \\
\text { matched con- } \\
\text { trols (n = I00); } \\
2 \% \text { diabetics; } \\
\text { average BMI } 29 ; \\
\text { average TG I43 } \\
\text { mg/dl }\end{array}$ & 200 & $\begin{array}{l}\text { Non-fatal myocar- } \\
\text { dial infarction }\end{array}$ & $\begin{array}{l}\text { Case } \\
\text { control }\end{array}$ & $\begin{array}{l}\text { Multivariate; risk } \\
\text { is expressed per } \\
\text { I mg/dl increase } \\
\text { in lipid param- } \\
\text { eters }\end{array}$ & $\begin{array}{l}\mathrm{I} .03(\mathrm{I} .0 \mathrm{I}-\mathrm{I} .05) \\
\text { per Img/dl } \\
\text { increase }\end{array}$ & $\begin{array}{l}\mathrm{I} .02(\mathrm{I} .0 \mathrm{I}-\mathrm{I} .03) \\
\text { per Img/dl } \\
\text { increase }\end{array}$ & $\begin{array}{l}\mathrm{I} .02(\mathrm{I} .0 \mathrm{I}-\mathrm{I} .04) \\
\text { per I mg/dl } \\
\text { increase }\end{array}$ & $\begin{array}{l}\text { Rallidis } \\
\text { et al } 2005\end{array}$ \\
\hline
\end{tabular}

Abbreviations: BMI, body mass index; CAD, coronary artery disease; HDL-C, high density lipoprotein cholesterol; LDL-C, low density lipoprotein cholesterol; NS, not significant; NA, not available; HR, hazard ratio;TG, triglycerides. 
predicting cardiovascular events in this primary prevention, female cohort. Likewise, in a diabetic male cohort $(n=746)$ with high TG (average $182 \mathrm{mg} / \mathrm{dl}$ ), apoB was not superior to non-HDL-C in predicting cardiovascular events (Jiang et al 2004). In contrast, other studies have suggested that apoB is a superior predictor of cardiovascular events than non-HDL-C (Pischon et al 2005, Bruno et al 2006, Chien et al 2007) and a stronger correlate with markers of obesity (Sattar et al 2004). Further, apoB may be the superior risk marker in those aged $>70$ years since there is a well described 'reverse epidemiology' that occurs in elderly populations whereby high lipids may be protective and hypocholesterolemia may represent a measure of frailty or selection bias (Bruno et al 2006).

\section{Perspective}

While multiple prospective cohort studies show that non-HDL-C is superior to LDL-C in cardiovascular risk prognostication, to become the primary target of therapy non-HDL-C would also have to predict cardiovascular events in patients on statins. As shown in Table 2, the 4S investigators have shown non-HDL-C to predict cardiovascular events in patients using Simvastatin (Pedersen et al 1998). Also, an analysis from the Greek Atorvastatin and Coronary Heart Disease evaluation (GREACE) study showed that the relative risk reduction of cardiovascular events in patients prescribed Atorvastatin was highly correlated with percentage reductions in non-HDL-C (Athyros et al 2003). Further, in this study, the percentage reduction in hard clinical endpoints correlated more strongly with reductions in non-HDL-C than LDL-C (Athyros et al 2003). Hence, the familiar linear relationship between relative risk reduction in $\mathrm{CAD}$ death or non-fatal myocardial infarction and LDL-C reduction with statins (Robinson et al 2005), if repeated with non-HDL-C may show stronger correlation and higher concordance. In this context, retrospective analyses of existing data and future inclusion of non-HDL-C as a primary outcome of lipid-lowering trials is strongly encouraged. The implications of such a shift in the primary target of therapy would probably mean intensification of lipid lowering therapy for patients with CAD or those who are at high risk for CAD. For instance, in the ACCESS program, patients with CAD had higher non-HDL-C (and $\mathrm{ApoB}$ ) relative to LDL-C and since fewer patients reached non-HDL-C targets than LDL-C, the use of a non-HDL-C could conceivably lead to the appropriate intensification of therapy for a large number of patients (Ballantyne et al 2001). Data from the NCEP Program Evaluation Project Utilizing Novel E-Technology (NEPTUNE) II Survey also support the notion that the adoption of non-HDL-C would lead to the appropriate intensification of therapy in patients with CAD or its risk equivalents. For instance, the NEPTUNE II survey reported that in the cohort of CAD patients with TG>200 mg/dl, 57\% were at the LDL-C goal of $<100$ $\mathrm{mg} / \mathrm{dl}$ while a mere $33 \%$ of patients achieved both LDL-C $<100 \mathrm{mg} / \mathrm{dl}$ and non-HDL-C $<130 \mathrm{mg} / \mathrm{dl}$ (Davidson et al 2005). Hence, the adoption of non-HDL-C as the primary target of therapy could have multiple advantages. Firstly, it is easier to calculate and its routine measurement is not limited to patients with $\mathrm{TG}<400 \mathrm{mg} / \mathrm{dl}$ or fasting specimens (Hsia 2003). Secondly, it is superior to LDL-C in determining cardiovascular risk 'across the board'. Thirdly, its superiority over LDL-C seems to be especially pertinent to the obese, which is a considerable proportion of the world. Fourthly, it appears that non-HDL-C predicts events in patients on statin therapy although this point in particular requires further clarification. Without doubt, non-HDL-C will be the lipid target of the future. With time, the definition of obesity has evolved from an assessment of body mass to BMI to the current assessment with waist circumference. Similarly, the primary target of lipid lowering therapy will have to evolve in a society that is increasingly obese.

\section{References}

Abate N, Vega GL, Grundy SM. 1993. Variability in cholesterol content and physical properties of lipoproteins containing apolipoprotein B-100. Atherosclerosis, 104:159-71.

Alexander CM, Landsman PB, Teutsch SM, et al. 2003. NCEP-Defined metabolic syndrome, diabetes, and prevalence of coronary heart disease among NHANES III participants age 50 Years and older. Diabetes, 52:1210-14.

Athyros VG, Papageorgiou AA, Symeonidis AN, et al. 2003. Non-high density lipoprotein cholesterol and coronary events during long-term statin treatment. Atherosclerosis, 168:397-8.

[ATPIII] Adult Treatment Panel III. 2002. Third Report of the National Cholesterol Education Program (NCEP) Expert Panel on Detection, Evaluation, and Treatment of High Blood Cholesterol in Adults (Adult Treatment Panel III) final report. Circulation, 106:3143-421.

Ballantyne CM, Andrews TC, Hsia JA, et al. 2001. Correlation of nonhigh-density lipoprotein cholesterol with apolipoprotein B: effect of 5 hydroxymethylglutaryl coenzyme A reductase inhibitors on non-highdensity lipoprotein cholesterol levels. Am J Cardiol, 88:265-9.

Barr ELM, Zimmet PZ, Welborn TA, et al. 2007. Risk of cardiovascular and all-cause mortality in individuals with diabetes mellitus, impaired fasting glucose, and impaired glucose tolerance. The Australian Diabetes, Obesity, and Lifestyle Study (AusDiab). Circulation, 116:151-7.

Barrett PH, Watts GF. 2003. Kinetic studies of lipoprotein metabolism in the metabolic syndrome including effects of nutritional interventions. Curr Opin Lipidol, 14:61-8.

Barter PJ, Ballantyne CM, Carmena R, et al. 2006. Apo B versus cholesterol in estimating cardiovascular risk and in guiding therapy: report of the thirty-person/ten-country panel. J Intern Med, 259:247-58.

Bennion LJ, Grundy SM. 1977. Effects of diabetes mellitus on cholesterol metabolism in man. $N$ Engl J Med, 296:1365-71.

Bittner V. 2004. Non-high-density lipoprotein cholesterol: an alternate target for lipid-lowering therapy. Prev Cardiol, 7:122-6. 
Bittner V, Hardison R, Kelsey SF, et al. 2002. Non-high-density lipoprotein cholesterol levels predict five-year outcome in the Bypass Angioplasty Revascularization Investigation (BARI). Circulation, 106:2537-42.

Bonora E. 2006. The metabolic syndrome and cardiovascular disease. Ann Med, 38:64-80.

Bonora E, Targher G, Alberiche M, et al. 2000. Homeostasis model assessment closely mirrors the glucose clamp technique in the assessment of insulin sensitivity: studies in subjects with various degrees of glucose tolerance and insulin sensitivity. Diabetes Care, 23:57-63.

Bos G, Dekker JM, Nijpels G, et al. 2003. A combination of high concentrations of serum triglyceride and non-high-density-lipoproteincholesterol is a risk factor for cardiovascular disease in subjects with abnormal glucose metabolism--The Hoorn Study. Diabetologia, 46:910-16.

Briones ER, Steiger DL, Palumbo PJ, et al. 1986. Sterol excretion and cholesterol absorption in diabetics and nondiabetics with and without hyperlipidemia. Am J Clin Nutr, 44:353-61.

Brownell KD, Stunkard AJ. 1981. Differential changes in plasma highdensity lipoprotein-cholesterol levels in obese men and women during weight reduction. Arch Intern Med, 141:1142-6.

Bruno G, Merletti F, Biggeri A, et al. 2006. Effect of age on the association of non-high-density-lipoprotein cholesterol and apolipoprotein B with cardiovascular mortality in a Mediterranean population with type 2 diabetes: the Casale Monferrato study. Diabetologia, 49:937-44.

Burke JP, Williams K, Gaskill SP, et al. 1999. Rapid rise in the incidence of type 2 diabetes from 1987 to 1996: results from the San Antonio Heart Study. Arch Intern Med, 159:1450-6.

Butler J, Rodondi N, Zhu Y, et al. 2006. Metabolic syndrome and the risk of cardiovascular disease in older adults. $J$ Am Coll Cardiol, 47:1595-602.

Carr DB, Utzschneider KM, Hull RL, et al. 2004. Intra-abdominal fat is a major determinant of the National Cholesterol Education Program Adult Treatment Panel III criteria for the metabolic syndrome. Diabetes, 53:2087-94.

Case CC, Jacobson TA, Roberts S, et al. 2003. Management of persons with high risk of coronary heart disease but low serum low-density lipoprotein cholesterol. Am J Cardiol, 91:1134-6.

Chan DC, Watts GF, Barrett PHR, et al. 2003. Plasma markers of cholesterol homeostasis and apolipoprotein B-100 kinetics in the metabolic syndrome. Obesity Res, 11:591-6.

Chien K-L, Hsu H-C, Su T-C, et al. 2007. Apolipoprotein B and non-highdensity lipoprotein cholesterol and risk of coronary heart disease in Chinese. J Lipid Res, 48:2499-505.

Cowie CC, Rust KF, Byrd-Holt DD, et al. 2006. Prevalence of diabetes and impaired fasting glucose in adults in the U.S. population: National Health and Nutrition Examination Survey 1999-2002. Diabetes Care, 29:1263-8.

Cui Y, Blumenthal RS, Flaws JA, et al. 2001. Non-high-density lipoprotein cholesterol level as a predictor of cardiovascular disease mortality. Arch Intern Med, 161:1413-19.

Davidson MH, Maki KC, Pearson TA, et al. 2005. Results of the National Cholesterol Education (NCEP) Program Evaluation ProjecT Utilizing Novel E-Technology (NEPTUNE) II survey and implications for treatment under the recent NCEP Writing Group recommendations. Am $J$ Cardiol, 96:556-63.

Denke MA, Sempos CT, Grundy SM. 1993. Excess body weight. An underrecognized contributor to high blood cholesterol levels in white American men. Arch Intern Med, 153:1093-103.

Denke MA, Sempos CT, Grundy SM. 1994. Excess body weight. An underrecognized contributor to dyslipidemia in white American women. Arch Intern Med, 154:401-10.

El Harchaoui K, van der Steeg WA, Stroes ES, et al. 2007. Value of lowdensity lipoprotein particle number and size as predictors of coronary artery disease in apparently healthy men and women: the EPIC-Norfolk Prospective Population Study. J Am Coll Cardiol, 49:547-53.

Flegal KM, Carroll MD, Ogden CL, et al. 2002. Prevalence and trends in obesity among US adults 1999-2000. JAMA, 288:1723-7.
Follick MJ, Abrams DB, Smith TW, et al. 1984. Contrasting short- and long-term effects of weight loss on lipoprotein levels. Arch Intern Med, 144:1571-4.

Ford ES, Giles WH, Mokdad AH. 2004. Increasing prevalence of the metabolic syndrome among U.S. adults. Diabetes Care, 27:2444-9.

Ford ES, Mokdad AH, Giles WH. 2003. Trends in waist circumference among U.S. adults. Obesity Res, 11:1223-31.

Foster CJ, Weinsier RL, Birch R, et al. 1987. Obesity and serum lipids: an evaluation of the relative contribution of body fat and fat distribution to lipid levels. Int J Obes, 11:151-61.

Fox CS, Coady S, Sorlie PD, et al. 2007. Increasing cardiovascular disease burden due to diabetes mellitus: The Framingham Heart Study. Circulation, 115:1544-50.

Fox CS, Massaro JM, Hoffmann U, et al. 2007. Abdominal visceral and subcutaneous adipose tissue compartments: association with metabolic risk factors in the Framingham Heart Study. Circulation, 116:39-48

Fox CS, Pencina MJ, Meigs JB, et al. 2006. Trends in the incidence of type 2 diabetes mellitus from the 1970s to the 1990s: The Framingham Heart Study. Circulation, 113:2914-18.

Friedland O, Nemet D, Gorodnitsky N, et al. 2002. Obesity and lipid profiles in children and adolescents. J Pediatr Endocrinol Metab, 15:1011-16.

Frost PH, Davis BR, Burlando AJ, et al. 1996. Serum Lipids and incidence of coronary heart disease: Findings from the Systolic Hypertension in the Elderly Program (SHEP). Circulation, 94:2381-8.

Gardner CD, Winkleby MA, Fortmann SP. 2000. Population frequency distribution of non-high-density lipoprotein cholesterol (Third National Health and Nutrition Examination Survey [NHANES III], 1988-1994). Am J Cardiol, 86:299-304.

Genest J, Frohlich J, Fodor G, et al. 2003. Recommendations for the management of dyslipidemia and the prevention of cardiovascular disease: summary of the 2003 update. CMAJ, 169:921-4.

Gordon DJ, Probstfield JL, Garrison RJ, et al. 1989. High-density lipoprotein cholesterol and cardiovascular disease. Four prospective American studies. Circulation, 79:8-15.

Grundy SM. 2005. A constellation of complications: The metabolic syndrome. Clin Cornerstone, 7:36-45.

Grundy SM. 2006. Metabolic syndrome: connecting and reconciling cardiovascular and diabetes worlds. J Am Coll Cardiol, 47:1093-100.

Grundy SM, Cleeman JI, Daniels SR, et al. 2005. Diagnosis and Management of the Metabolic Syndrome: An American Heart Association/National Heart, Lung, and Blood Institute Scientific Statement. Circulation, 112:2735-52.

Grundy SM, Cleeman JI, Merz CN, et al. 2004. Implications of recent clinical trials for the National Cholesterol Education Program Adult Treatment Panel III guidelines. Circulation, 110:227-39.

Gylling H, Miettinen TA. 1997. Cholesterol absorption, synthesis, and LDL metabolism in NIDDM. Diabetes Care, 20:90-5.

Haffner SM, Lehto S, Ronnemaa T, et al. 1998. Mortality from coronary heart disease in subjects with type 2 diabetes and in nondiabetic subjects with and without prior myocardial infarction. $N$ Engl $J$ Med, 339:229-34.

Hoenig MR, Kostner KM, Read SJ, et al. 2007. Implications of the obesity epidemic for statin therapy: shifting cholesterol metabolism to a high synthesis and low dietary absorption state. Endocr Metab Immune Disord Drug Targets, 7:153-66.

Howard BV, Best LG, Galloway JM, et al. 2006. Coronary heart disease risk equivalence in diabetes depends on concomitant risk factors. Diabetes Care, 29:391-7.

Howard BV, Robbins DC, Sievers ML, et al. 2000. LDL cholesterol as a strong predictor of coronary heart disease in diabetic individuals with insulin resistance and low LDL: The Strong Heart Study. Arterioscler Thromb Vasc Biol, 20:830-5.

Hsia SH. 2003. Non-HDL Cholesterol: Into the Spotlight. Diabetes Care, $26: 240-2$. 
Hulthe J, Bokemark L, Wikstrand J, et al. 2000. The metabolic syndrome, LDL particle size, and atherosclerosis: The Atherosclerosis and Insulin Resistance (AIR) Study. Arterioscler Thromb Vasc Biol, 20:2140-7.

Ingelsson E, Schaefer EJ, Contois JH, et al. 2007. Clinical utility of different lipid measures for prediction of coronary heart disease in men and women. JAMA, 298:776-85.

Jacobs DR Jr., Burke GL, Liu K, et al. 1988. Relationships of low density lipoprotein cholesterol with age and other factors: a cross-sectional analysis of the CARDIA study. Ann Clin Res, 20:32-8.

Jiang R, Schulze MB, Li T, et al. 2004. Non-HDL cholesterol and apolipoprotein $\mathrm{B}$ predict cardiovascular disease events among men with type 2 diabetes. Diabetes Care, 27:1991-7.

Kathiresan S, Otvos JD, Sullivan LM, et al. 2006. Increased small low-density lipoprotein particle number: A prominent feature of the metabolic syndrome in the Framingham Heart Study. Circulation, 113:20-9.

Kempen H, Glatz J, Gevers Leuven J, et al. 1988. Serum lathosterol concentration is an indicator of whole-body cholesterol synthesis in humans. J. Lipid Res, 29:1149-55.

Keys A, Karvonen MJ, Punsar S, et al. 1984. HDL serum cholesterol and 24-year mortality of men in Finland. Int J Epidemiol, 13:428-35.

Lakka H-M, Laaksonen DE, Lakka TA, et al. 2002. The metabolic syndrome and total and cardiovascular disease mortality in middle-aged men. JAMA, 288:2709-16.

Lamon-Fava S, Wilson PWF, Schaefer EJ. 1996. Impact of body mass index on coronary heart disease risk factors in men and women: The Framingham Offspring Study. Arterioscler Thromb Vasc Biol, 16:1509-15.

Lehto S, Ronnemaa T, Haffner SM, et al. 1997. Dyslipidemia and hyperglycemia predict coronary heart disease events in middle-aged patients with NIDDM. Diabetes, 46:1354-9.

Liberopoulos EN, Mikhailidis DP, Elisaf MS. 2005. Diagnosis and management of the metabolic syndrome in obesity. Obes Rev, 6:283-96.

Liu J, Sempos C, Donahue RP, et al. 2005. Joint distribution of non-HDL and LDL cholesterol and coronary heart disease risk prediction among individuals with and without diabetes. Diabetes Care, 28:1916-21.

Liu J, Sempos CT, Donahue RP, et al. 2006. Non-high-density lipoprotein and very-low-density lipoprotein cholesterol and their risk predictive values in coronary heart disease. Am J Cardiol, 98:1363-8.

[LRC] Lipid Research Clinics. 1979. Plasma lipid distributions in selected North American populations: the Lipid Research Clinics Program Prevalence Study. The Lipid Research Clinics Program Epidemiology Committee. Circulation, 60:427-39.

[LRC] Lipid Research Clinics. 1984a. The Lipid Research Clinics Coronary Primary Prevention Trial results. I. Reduction in incidence of coronary heart disease. JAMA, 251:351-64.

[LRC] Lipid Research Clinics. 1984b. The Lipid Research Clinics Coronary Primary Prevention Trial results. II. The relationship of reduction in incidence of coronary heart disease to cholesterol lowering. JAMA, 251:365-74.

Lu W, Resnick HE, Jablonski KA, et al. 2003. Non-HDL cholesterol as a predictor of cardiovascular disease in type 2 diabetes: The Strong Heart Study. Diabetes Care, 26:16-23.

Mack WJ, Krauss RM, Hodis HN. 1996. Lipoprotein subclasses in the monitored Atherosclerosis Regression Study (MARS): Treatment effects and relation to coronary angiographic progression. Arterioscler Thromb Vasc Biol, 16:697-704.

Malik S, Wong ND, Franklin SS, et al. 2004. Impact of the metabolic syndrome on mortality from coronary heart disease, cardiovascular disease, and all causes in United States adults. Circulation, 110:1245-50.

McNamara DJ, Kolb R, Parker TS, et al. 1987. Heterogeneity of cholesterol homeostasis in man. Response to changes in dietary fat quality and cholesterol quantity. J Clin Invest, 79:1729-39.

Meilahn EN, Kuller LH, Stein EA, et al. 1988. Characteristics associated with apoprotein and lipoprotein lipid levels in middle-aged women. Arteriosclerosis, 8:515-20.

Menotti A, Spagnolo A, Scanga M, et al. 1992. Multivariate prediction of coronary deaths in a 10 year follow-up of an Italian occupational male cohort. Acta Cardiol, 47:311-20.
Miettinen TA. 1971. Cholesterol production in obesity. Circulation, 44:842-50.

Nathan DM, Cleary PA, Backlund JY, et al. 2005. Intensive diabetes treatment and cardiovascular disease in patients with type 1 diabetes. $N$ Engl J Med, 353:2643-53.

Nestel PJ, Whyte HM, Goodman DS. 1969. Distribution and turnover of cholesterol in humans. $J$ Clin Invest, 48:982-91.

Nieves DJ, Cnop M, Retzlaff B, et al. 2003. The atherogenic lipoprotein profile associated with obesity and insulin resistance is largely attributable to intra-abdominal fat. Diabetes, 52:172-9.

Nigam A, Bourassa MG, Fortier A, et al. 2006. The metabolic syndrome and its components and the long-term risk of death in patients with coronary heart disease. Am Heart J, 151:514-21.

Ogden CL, Carroll MD, Curtin LR, et al. 2006. Prevalence of overweight and obesity in the United States, 1999-2004. JAMA, 295:1549-55.

Pedersen TR, Olsson AG, Færgeman O, et al. 1998. Lipoprotein changes and reduction in the incidence of major coronary heart disease events in the Scandinavian Simvastatin Survival Study (4S). Circulation, 97:1453-60

Phillips N, Waters D, Havel R. 1993. Plasma lipoproteins and progression of coronary artery disease evaluated by angiography and clinical events. Circulation, 88:2762-70.

Pischon T, Girman CJ, Sacks FM, et al. 2005. Non-high-density lipoprotein cholesterol and apolipoprotein B in the prediction of coronary heart disease in men. Circulation, 112, 3375-83.

Pladevall M, Singal B, Williams LK, et al. 2006. A single factor underlies the metabolic syndrome: A confirmatory factor analysis. Diabetes Care, 29:113-22.

Pocock SJ, Shaper AG, Phillips AN, et al. 1986. High density lipoprotein cholesterol is not a major risk factor for ischaemic heart disease in British men. Br Med J (Clin Res Ed), 292:515-19.

Rallidis LS, Pitsavos C, Panagiotakos DB, et al. 2005. Non-high density lipoprotein cholesterol is the best discriminator of myocardial infarction in young individuals. Atherosclerosis, 179:305-9.

Reed D, Benfante R. 1992. Lipid and lipoprotein predictors of coronary heart disease in elderly men in the Honolulu Heart Program. Ann Epidemiol, 2:29-34.

Ridker PM, Rifai N, Cook NR, et al. 2005. Non-HDL cholesterol, apolipoproteins A-I and B100, standard lipid measures, lipid ratios, and CRP as risk factors for cardiovascular disease in women. JAMA, 294:326-33.

Robinson JG, Smith B, Maheshwari N, et al. 2005. Pleiotropic effects of statins: benefit beyond cholesterol reduction? A meta-regression analysis. J Am Coll Cardiol, 46:1855-62.

Rossouw JE, Lewis B, Rifkind BM. 1990. The value of lowering cholesterol after myocardial infarction. $N$ Engl J Med, 323:1112-19.

Sacks FM, Alaupovic P, Moye LA, et al. 2000. VLDL, apolipoproteins B, $\mathrm{CIII}$, and $\mathrm{E}$, and risk of recurrent coronary events in the Cholesterol and Recurrent Events (CARE) Trial. Circulation, 102:1886-92.

Sattar N, Williams K, Sniderman AD, et al. 2004. Comparison of the associations of apolipoprotein B and non-high-density lipoprotein cholesterol with other cardiovascular risk factors in patients with the metabolic syndrome in the Insulin Resistance Atherosclerosis Study. Circulation, 110:2687-93.

Schaefer EJ, Lamon-Fava S, Johnson S, et al. 1994. Effects of gender and menopausal status on the association of apolipoprotein E phenotype with plasma lipoprotein levels. Results from the Framingham Offspring Study. Arterioscler Thromb, 14:1105-13.

Schulze MB, Shai I, Manson JE, et al. 2004. Joint role of non-HDL cholesterol and glycated haemoglobin in predicting future coronary heart disease events among women with type 2 diabetes. Diabetologia, 47:2129-36.

Shepherd J. 2005. Does statin monotherapy address the multiple lipid abnormalities in type 2 diabetes? Atheroscler Suppl, 6:15-19.

Simonen P, Gylling H, Howard AN, et al. 2000. Introducing a new component of the metabolic syndrome: low cholesterol absorption. Am J Clin Nutr, 72:82-8. 
Simonen PP, Gylling HK, Miettinen TA. 2002. Diabetes contributes to cholesterol metabolism regardless of obesity. Diabetes Care, 25:1511-15.

Sniderman AD, Furberg CD, Keech A, et al. 2003. Apolipoproteins versus lipids as indices of coronary risk and as targets for statin treatment. Lancet, 361:777-80

Sniderman AD, St-Pierre AC, Cantin B, et al. 2003. Concordance/discordance between plasma apolipoprotein B levels and the cholesterol indexes of atherosclerotic risk. Am J Cardiol, 91:1173-7.

Srinivasan SR, Frontini MG, Xu J, et al. 2006. Utility of childhood non-highdensity lipoprotein cholesterol levels in predicting adult dyslipidemia and other cardiovascular risks: The Bogalusa Heart Study. Pediatrics, 118:201-6.

Srinivasan SR, Myers L, Berenson GS. 2002. Distribution and correlates of non-high-density lipoprotein cholesterol in children: The Bogalusa Heart Study. Pediatrics, 110:e29.

Stamler J, Stamler R, Brown W, et al. 1993. Serum cholesterol. Doing the right thing. Circulation, 88:1954-60.

Stamler J, Wentworth D, Neaton JD. 1986. Is relationship between serum cholesterol and risk of premature death from coronary heart disease continuous and graded? Findings in 356,222 primary screenees of the Multiple Risk Factor Intervention Trial (MRFIT). JAMA, 256:2823-8.

St-Pierre AC, Cantin B, Dagenais GR, et al. 2006. Apolipoprotein-B, lowdensity lipoprotein cholesterol, and the long-term risk of coronary heart disease in men. Am J Cardiol, 97:997-1001.

St-Pierre AC, Cantin B, Dagenais GR, et al. 2005. Low-density lipoprotein subfractions and the long-term risk of ischemic heart disease in men: 13-year follow-up data from the Quebec Cardiovascular Study. Arterioscler Thromb Vasc Biol, 25:553-9.
St-Pierre AC, Ruel IL, Cantin B, et al. 2001. Comparison of various electrophoretic characteristics of ldl particles and their relationship to the risk of ischemic heart disease. Circulation, 104:2295-9.

Vaccaro O, Stamler J, Neaton JD. 1998. Sixteen-year coronary mortality in black and white men with diabetes screened for the Multiple Risk Factor Intervention Trial (MRFIT). Int J Epidemiol, 27:636-41.

Walldius G, Jungner I, Holme I, et al. 2001. High apolipoprotein B, low apolipoprotein A-I, and improvement in the prediction of fatal myocardial infarction (AMORIS study): a prospective study. Lancet, 358:2026-33.

Wilson PW, D'Agostino RB, Levy D, et al. 1998. Prediction of coronary heart disease using risk factor categories. Circulation, 97:1837-47.

Wolf R, Grundy S. 1983a. Influence of weight reduction on plasma lipoproteins in obese patients. Arterioscler Thromb Vasc Biol, 3:160-9.

Wolf RN, Grundy SM. 1983b. Influence of weight reduction on plasma lipoproteins in obese patients. Arteriosclerosis, 3:160-9.

Wong ND, Wilson PW, Kannel WB. 1991. Serum cholesterol as a prognostic factor after myocardial infarction: the Framingham Study. Ann Intern Med, 115:687-93.

Wood PD, Stefanick ML, Dreon DM, et al. 1988. Changes in plasma lipids and lipoproteins in overweight men during weight loss through dieting as compared with exercise. $N$ Engl J Med, 319:1173-9.

Yusuf S, Hawken S, Ounpuu S, et al. 2005. Obesity and the risk of myocardial infarction in 27,000 participants from 52 countries: a case-control study. Lancet, 366:1640-9.

Zimmet P, Magliano D, Matsuzawa Y, et al. 2005. The metabolic syndrome: a global public health problem and a new definition. $J$ Atheroscler Thromb, 12:295-300. 